\title{
The role of mixotrophic protists in the biological carbon pump
}

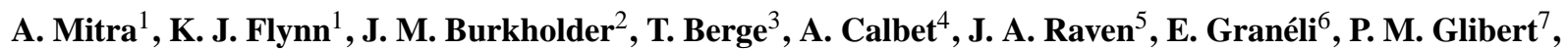 \\ P. J. Hansen ${ }^{3}$, D. K. Stoecker ${ }^{7}$, F. Thingstad ${ }^{8}$, U. Tillmann ${ }^{9}$, S. Våge ${ }^{8}$, S. Wilken ${ }^{10}$, and M. V. Zubkov ${ }^{11}$ \\ ${ }^{1}$ Centre for Sustainable Aquatic Research (CSAR), Swansea University, Swansea SA2 8PP, UK \\ ${ }^{2}$ Center for Applied Aquatic Ecology, North Carolina State University, 620 Hutton Street - Suite 104, Raleigh, \\ NC 27606, USA \\ ${ }^{3}$ Centre for Ocean Life, Marine Biological Section, University of Copenhagen, Strandpromenaden 5, \\ 3000 Helsingør, Denmark \\ ${ }^{4}$ Institut de Ciències del Mar (CSIC). Passeig Marítim de la Barceloneta, 37-49, 08003 Barcelona, Spain \\ ${ }^{5}$ Division of Plant Sciences, University of Dundee at the James Hutton Institute, Invergowrie, Dundee DD2 5DA, UK \\ ${ }^{6}$ Marine Sciences Centre, Linnaeus University, 39182 Kalmar, Sweden \\ ${ }^{7}$ University of Maryland Center for Environmental Science, Horn Point Laboratory, P.O. Box 775, Cambridge, \\ MD 21613, USA \\ ${ }^{8}$ Department of Biology, University of Bergen, P.O. Box 7803, 5020 Bergen, Norway \\ ${ }^{9}$ Alfred Wegener Institute for Polar and Marine Research, Am Handelshafen 12, 27570 Bremerhaven, Germany \\ ${ }^{10}$ Monterey Bay Aquarium Research Institute (MBARI), 7700 Sandholdt Road, Moss Landing, CA 95039-0628, USA \\ ${ }^{11}$ National Oceanography Centre, European Way, Southampton, SO14 3ZH, UK
}

Correspondence to: A. Mitra (a.mitra@swansea.ac.uk)

Received: 31 July 2013 - Published in Biogeosciences Discuss.: 15 August 2013

Revised: 6 January 2014 - Accepted: 7 January 2014 - Published: 20 February 2014

\begin{abstract}
The traditional view of the planktonic food web describes consumption of inorganic nutrients by photoautotrophic phytoplankton, which in turn supports zooplankton and ultimately higher trophic levels. Pathways centred on bacteria provide mechanisms for nutrient recycling. This structure lies at the foundation of most models used to explore biogeochemical cycling, functioning of the biological pump, and the impact of climate change on these processes. We suggest an alternative new paradigm, which sees the bulk of the base of this food web supported by protist plankton communities that are mixotrophic - combining phototrophy and phagotrophy within a single cell. The photoautotrophic eukaryotic plankton and their heterotrophic microzooplankton grazers dominate only during the developmental phases of ecosystems (e.g. spring bloom in temperate systems). With their flexible nutrition, mixotrophic protists dominate in more-mature systems (e.g. temperate summer, established eutrophic systems and oligotrophic systems); the more-stable water columns suggested under climate change may also be expected to favour these mixotrophs. We explore how such a predominantly mixotrophic structure af-
\end{abstract}

fects microbial trophic dynamics and the biological pump. The mixotroph-dominated structure differs fundamentally in its flow of energy and nutrients, with a shortened and potentially more efficient chain from nutrient regeneration to primary production. Furthermore, mixotrophy enables a direct conduit for the support of primary production from bacterial production. We show how the exclusion of an explicit mixotrophic component in studies of the pelagic microbial communities leads to a failure to capture the true dynamics of the carbon flow. In order to prevent a misinterpretation of the full implications of climate change upon biogeochemical cycling and the functioning of the biological pump, we recommend inclusion of multi-nutrient mixotroph models within ecosystem studies.

\section{Introduction}

The oceans support $\sim 46 \%$ of Earth's primary production, mainly through the phototrophic activities of protists and prokaryotic microbes that are at the base of the marine food 
web (Field et al., 1998). Classic texts relate physics and inorganic nutrients to the phototrophic producers (the phytoplankton), then to their consumers (as micro- and mesozooplankton), and ultimately to fisheries (Cushing, 1975, 1995); within this framework the role of the microbial loop (Azam et al., 1983; Gifford, 1991; Sherr and Sherr, 2002) is typically embedded. The term "biological pump" is often used, in association with the various oceanic physical and biological processes, to describe the sequestration of carbon produced by the oceanic biotic components into deeper waters. Thus the collective activity of marine microbes (i.e. archaea, bacteria, cyanobacteria, protists) together with their immediate trophic associates (zooplankton such as copepods and salps) drive the biological pump through production of particulate organic material (POM) that sinks from the upper mixed waters. While POM has a clear role within the biological pump, the role of long-lived forms of dissolved organic material (DOM) as a reservoir of $\mathrm{C}$ remains controversial (Azam and Worden, 2004; Hansell et al., 2009; Jiao et al., 2010).

Most of the energy and material in the marine food web flows through protists, organisms that are traditionally seen as eukaryotic phytoplankton and microzooplankton. In the evolution of these protists, phagotrophy is the ancestral state and phototrophy is the derived, more recent, state (Raven et al., 2009). This evolutionary pathway, which is neither fixed nor irreversible, has included a multitude of events associated with acquisition of structures and of symbionts that have led to the evolution of organelles including plastids and other characteristics (de Castro et al., 2009; Stoecker et al., 2009). "Strict" phototrophy and "strict" phagotrophy thus form the two extreme ends of a spectrum, with most protist groups in the photic zone functionally occupying the intermediate niche zone as mixotrophs. In fact, evolution to the extent of rejecting phagotrophy completely appears to be restricted to a few, albeit important, groups of protists, most notably the diatoms.

We define mixotrophy in protists as the dual capability of engaging phototrophy and phagotrophy within a single cell. Consistent with our previous arguments (Flynn et al., 2013), osmotrophy has not been included here as a discriminatory characteristic for mixotrophy in protists. The primary reason is that osmotrophy (uptake of dissolved organic substrates, vitamins and others) appears to be ubiquitous in these organisms, be they protists traditionally identified as phytoplankton or microzooplankton (Sanders, 1991a; Glibert and Legrand, 2006; Burkholder et al., 2008). For example, nonphagotrophic protists, such as diatoms, typically require organics such as vitamins (i.e. they are auxotrophic; Croft et al., 2006). Furthermore, osmotrophy alone does not have a direct powerful impact on trophic dynamics, as does the act of killing and engulfing a prey item through phagocytosis (Thingstad et al., 1996).

The varying proportions of phototrophic and phagotrophic activities in the mixotrophic protists (both for the indi- vidual cell and among species and strains) depend on the availability of light, nutrient and/or prey or other particles upon which to feed. Mixotrophy is not displayed by any unique taxonomic group but, rather, occurs amongst different species ranging over a variety of groups (Stoecker et al., 2009; Flynn et al., 2013). It is a common phenomenon occurring widely in marine (e.g. eutrophic, mesotrophic and oligotrophic, coastal to open-ocean systems; Pitta and Giannakourou, 2000; Burkholder et al., 2008; Hartmann et al., 2012; Sanders and Gast, 2012) as well as freshwater systems (Sanders, 1991a). Indeed, there is increasing evidence that in most aquatic systems the majority of protists are mixotrophs engaging in varying proportions of phototrophy and phagotrophy (Sanders, 1991b; Burkholder et al., 2008; Raven et al., 2009; Stoecker et al., 2009; Jeong et al., 2010; Lindehoff et al., 2010; Hansen, 2011; Johnson, 2011). Often the marine ecosystems are heavily dependent upon the activity of these mixotrophic protists (Pitta and Giannakourou, 2000; Unrein et al., 2007; Zubkov and Tarran, 2008; Hartmann et al., 2012; Sanders and Gast, 2012).

In light of the above, Flynn et al. (2013) proposed a marked shift in the way that aquatic protists are popularly characterized and subdivided. Instead of the traditional "black-and-white" view that characterizes typical marine microbial protists as being either phototrophic "phytoplankton" or phagotrophic "microzooplankton", they argued that a significant proportion of the protists in the photic zone are mixotrophic, and that aquatic scientists need to acknowledge this reality in empirical and theoretical studies. Stemming from this reappraisal, the revised marine food web paradigm conceptualizes the traditional phytoplanktonzooplankton structure as predominating only during short, though important, periods of the production cycle. These periods are characterized by pioneer species (akin to r-selected species; Parry, 1981) growing in developmental phases of ecosystems (Odum, 1969) exemplified by the spring bloom in temperate waters, or in upwelling waters (Fig. 1). They are typically associated with enhanced illumination and inorganic nutrient availability coupled with an absence of effective grazing control (Irigoien et al., 2005), favouring rapid proliferation of strict phototrophs (e.g. diatoms, and coccolithophorids during their strictly phototrophic stages; Rokitta et al., 2011). Such conditions lead to emergence of the strict phagotrophs as the dominant protist predators. However, as these waters and their ecosystems mature, their nutrient conditions and particulate organic loading change, giving rise to conditions that favour mixotrophy (Fig. 1). Therefore, during much of the planktonic production cycle these mixotrophs are abundant if not dominant. They support important events such as early-stage life cycles of many finfish and shellfish, and development of the autumn and overwintering zooplankton populations, which then impact upon the biogeochemistry of the following spring bloom (Cushing, 1995; Montagnes et al., 2010). 


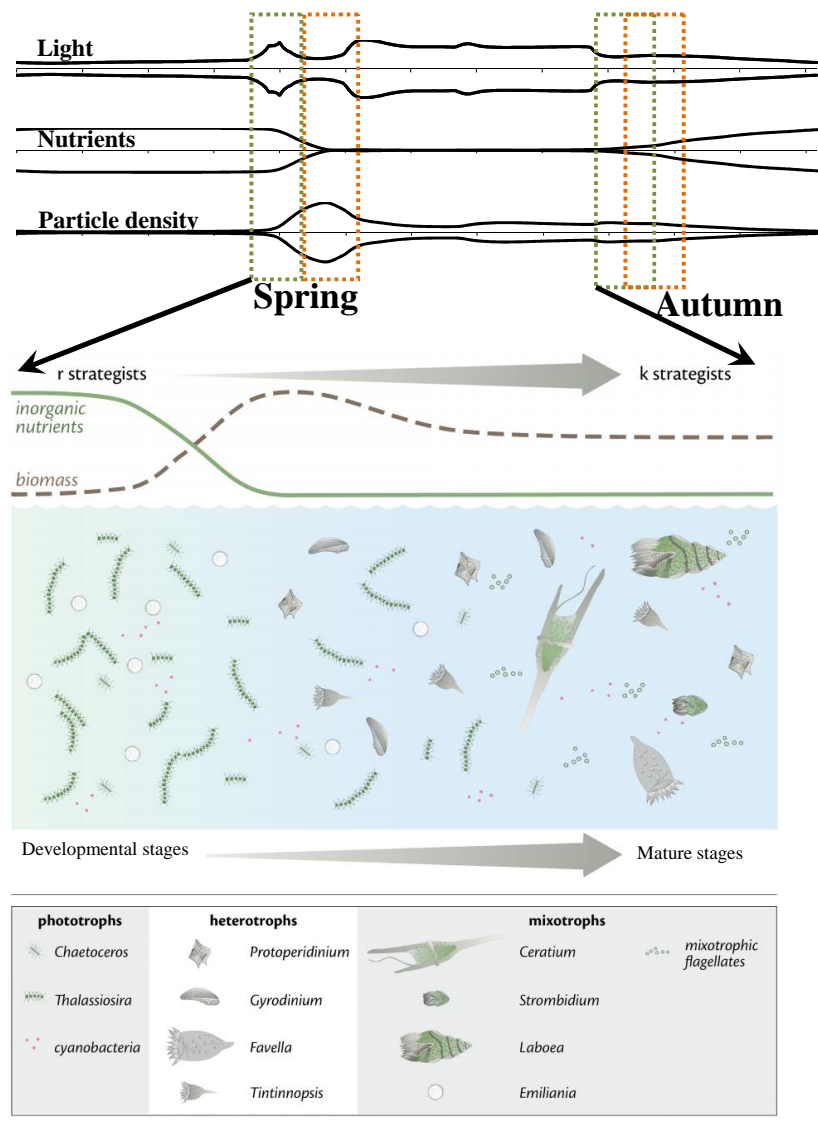

Fig. 1. Diagrammatic portrayal of the changes to the planktonic food web over a year, with transitions between ecosystem states. The upper panels show changing patterns of light, inorganic nutrients and particle density (i.e. total plankton biomass) over the temperate year. Transitions between developmental and mature stages of the ecosystem are as indicated; green and orange dashed lines indicate the developmental stages, where green represents conditions optimal for phototrophy and orange for phagotrophy. Later periods (transition to the more mature state) are suboptimal for strict phototrophs and/or strict phagotrophs, and more supportive for mixotrophs. The lower panel shows in detail the transition from developmental to mature stages, with changes in selection priorities from "r-selected" phototrophs and phagotrophs in the developmental phase of the ecosystem to a mature ecosystem with "Kselected" mixotrophs. For definitions and discussion of developmental vs. mature state, and r vs. K selection, see Odum (1969) and Parry (1981).

Most plankton ecologists and those working in allied fields of research (e.g. biological oceanographers, modellers) emphasize, mostly or entirely, the organisms representing the two extremes in the evolution of protists: the strictly heterotrophic microzooplankton and the strictly phototrophic phytoplankton. Mixotrophy is also ignored or marginalized in theoretical as well as modelling studies of aquatic ecosystems (Table 2 in Mitra et al., 2014). Thus, the nutrient-phytoplankton-zooplankton-bacteria (NPZB) food web models, which have been a feature of marine research for decades (Cushing, 1975, 1995; Fasham et al., 1990; Totterdell et al., 1993; Rose et al., 2010), do not include mixotroph functional types at all. Even more recent reviews focussing on the importance of microbial activity in global productivity and functioning of the biological pump make scant or no mention of the existence of mixotrophs (Azam and Worden, 2004; Jiao et al., 2010; Steele et al., 2010).

Here, we explore the ramifications of the proposed new paradigm for trophic dynamics within the plankton food web, demonstrating the need to consider the activities of the mixotrophic protists. We also show how exclusion of these organisms from conceptual and mathematical models misrepresents the functioning of the biological pump, with important implications for our understanding of the influence of climate change on aquatic ecosystems. For this work, we have considered an oligotrophic plankton food web framework because, while providing a relatively simple structure, the oligotrophic gyres are recognized to be the largest oceanic ecosystems (ca. $40 \%$ by area) and are spatially expanding at substantial annual and seasonal rates (Polovina et al., 2008; Hartmann et al., 2012).

\section{Methods}

\subsection{Food web framework}

In order to explore the role of mixotrophic protists, we compare the outputs from two contrasting in silico plankton food web structures operating in an oligotrophic setting, as detailed below.

(i) A traditional food web structure without an explicit description of mixotrophs (Fig. 2a), henceforth termed the "traditional paradigm". This framework includes non-motile microalgae (NMA) and photo-autotrophic nanoflagellates (ANFs) as primary producers (both being non-mixotrophic), bacteria as decomposers, heterotrophic nanoflagellates (HNFs) that ingest the bacteria, and microzooplankton $(\mu \mathrm{Z})$ which graze on the NMA, ANFs and HNFs. The $\mu \mathrm{Z}$ are in turn consumed by higher trophic levels (simulated here through a closure function; Mitra et al., 2007; cf. Mitra, 2009).

(ii) An alternative food web framework incorporating mixotrophs (Fig. 2b), henceforth termed the "new paradigm". This new paradigm includes the same components as the traditional paradigm, excepting one difference. The ANFs are now replaced with nanoflagellates that also engage in phagotrophy; that is, in keeping with our revised understanding, they are mixotrophic. These mixotrophic nanoflagellates (MNFs) in the new paradigm are de facto representatives of the mixotrophic flagellates observed within oligotrophic systems (Unrein et al., 2007; Zubkov 
(a) TRADITIONAL PARADIGM

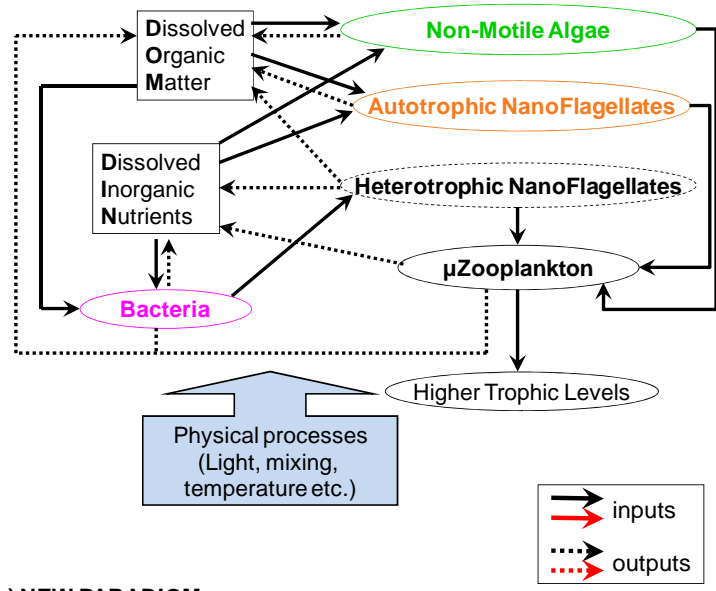

(b) NEW PARADIGM

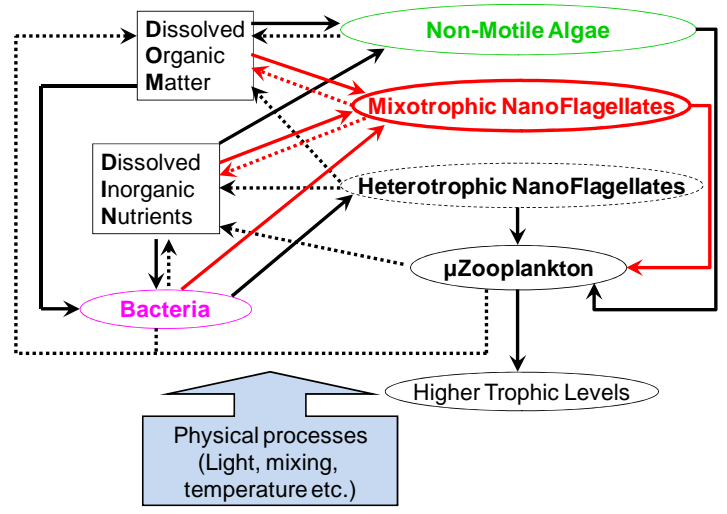

Fig. 2. Schematic representing the two alternate modelled food web structures. In the traditional paradigm (A) the physiology of the photoautotrophic flagellates (ANFs) is similar to that of the nonmotile microalgae (NMA); neither are mixotrophic. Inorganic nutrients for the support of primary production are regenerated via bacteria, heterotrophic nanoflagellates (HNFs) and phagotrophic microzooplankton $(\mu \mathrm{Z})$. In the new paradigm $(\mathbf{B})$, the ANFs are replaced with mixotrophic nanoflagellates (MNFs), conforming to our present understanding of protist physiology. The MNFs are capable of eating bacteria (red-lined black arrow), and hence deriving nutrients for the support of their growth, and of their primary production, directly rather than (for ANFs in panel A) via the activities of $\mathrm{HNFs}+\mu \mathrm{Z}$. Dashed arrows indicate functions contributing to nutrient pools (blue for inorganic, brown for organic). Heavy black arrows indicate predatory links.

and Tarran, 2008; Stukel et al., 2011; Hartmann et al., 2012). They photosynthesize using their intrinsic chloroplasts (for which they contain full genetic control; see Flynn and Hansen, 2013), while obtaining nutrition through the ingestion of bacteria, hence competing with the HNFs for bacterial prey. While mixotrophic algal protists have been shown to feed on a wide array of types and sizes of prey (Jeong et al.,
2010), in the system that we consider, bacteria are the primary prey item (Hartmann et al., 2012).

\subsection{Configuration of the model}

Six plankton functional types (bacteria, autotrophic NMA, ANFs, MNFs, HNF, and $\mu \mathrm{Z}$ ) were constructed using mechanistic acclimative plankton models, which have all been previously described (see below for references). The models were C-biomass-based, with explicit inclusion of $\mathrm{N}$ and $\mathrm{P}$. Variable $\mathrm{C}: \mathrm{N}: \mathrm{P}$ stoichiometry was simulated in those capable of phototrophy (NMA, ANFs and MNFs) and in the DOM. The bacteria, HNFs and $\mu \mathrm{Z}$ were assigned a fixed mass $\mathrm{C}: \mathrm{N}: \mathrm{P}$ stoichiometry of 50:10:1 (Mitra, 2006; Flynn and Mitra, 2009; Mitra and Flynn, 2010). Growth of those capable of phototrophy (NMA, ANFs and MNFs) contained components linking growth rates to their variable $\mathrm{C}: \mathrm{N}: \mathrm{P}$ physiology and to light through photoacclimation (variable Chl : C, Flynn, 2001).

The non-motile microalgal assemblage (NMA), consuming inorganic substrates as nitrate, ammonium and phosphate, and releasing dissolved organic carbon (DOC), was configured using the model of Flynn (2001). The bacterial assemblage consuming inorganic forms of $\mathrm{N}$ and $\mathrm{P}$, and labile and semi-labile dissolved organics was as described by Flynn (2005). Labile DOM was considered to have been generated directly as a function of $\mathrm{C}$ fixation (i.e. low-molecularweight primary metabolites; Hansell et al., 2009), while all other forms of DOM were semi-labile (sDOM); labile forms were used by preference and allocated as described in the bacteria model of Flynn (2005). The HNFs and $\mu \mathrm{Z}$ were described using the zooplankton model of Mitra (2006).

The ANF and MNF models were described using the model of Flynn and Mitra (2009), configured to consume nitrate, ammonium and phosphate and to release DOC and semi-labile organics. For the traditional paradigm, phagotrophy in this submodel was not enabled; in this form the model described ANFs. Allowing mixotrophy by enabling phagotrophy upon bacteria, this submodel described MNFs.

The HNFs and MNFs had only one prey option (bacteria; cell diameter, $0.45 \mu \mathrm{m}$; Andersson et al., 1986). However, the $\mu \mathrm{Z}$ could graze on NMA, ANFs, MNFs and HNFs. Prey selection by the $\mu \mathrm{Z}$ was a function of prey availability as related to prey numeric abundance and prey encounter, assuming cell diameters as follows: NMA, ANF/MNF, and HNFs of $3 \mu \mathrm{m}$, $3 \mu \mathrm{m}$, and $2.9 \mu \mathrm{m}$ respectively (Hartmann et al., 2012), and for $\mu \mathrm{Z}$ of $20 \mu \mathrm{m}$ (Pérez et al., 1997). Prey selectivity was implemented through a modified version of the ingestion-based selectivity function of Mitra and Flynn (2006a).

The interactions between the different plankton communities were modelled within a physical description of a mixed water column of $150 \mathrm{~m}$ depth. A low level of mixing (equivalent to a dilution rate of $0.01 \mathrm{~d}^{-1}$; see Fasham et al., 1990) between the mixed and lower water masses removed organisms and residual nutrients and introduced fresh nutrients 

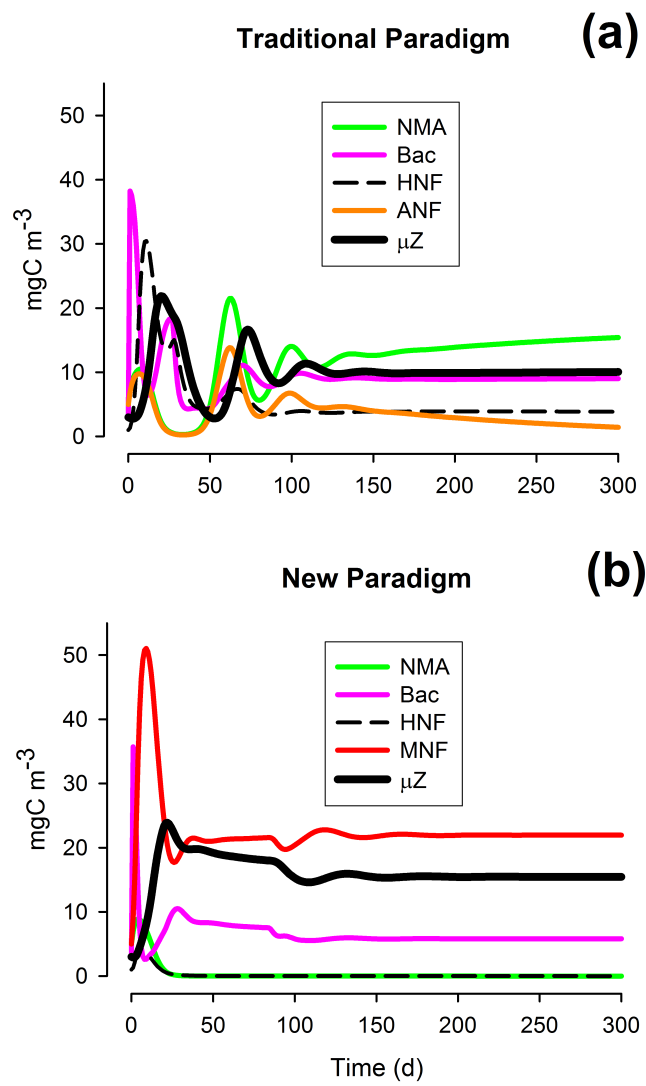

Fig. 3. Temporal pattern of the development of biomass in the simulated communities. In the traditional paradigm (A), the autotrophic nanoflagellates (ANFs) have no mixotrophic potential, while in the new paradigm (B) these nanoflagellates (as MNFs) exhibit mixotrophy (see also Fig. 2). The inorganic nutrient regimes used for this simulation (with an inorganic $\mathrm{N}$ input of $1 \mu \mathrm{M}$ ) was Redfield $\mathrm{N}: \mathrm{P}$ (molar ratio 16).

from the sub-mixed layer waters. The initial (and sub-mixed layer) dissolved inorganic nitrogen (DIN, as nitrate and ammonium at a ratio of $9: 1$ ) was assumed to be $1 \mu \mathrm{M}$. Phosphate was supplied at three different ratios relative to DIN: (i) Redfield ratio (molar $\mathrm{N}: \mathrm{P}=16$; Redfield, 1958), (ii) elevated (molar $\mathrm{N}: \mathrm{P}=64$, imparting $\mathrm{P}$ stress), or (iii) depressed (molar $\mathrm{N}: \mathrm{P}=4$, for $\mathrm{N}$ stress). To provide a source of organics to support bacterial growth, the initial (and sub-mixed layer) semi-labile dissolved organic nitrogen (sDOM-N) was assumed to be $0.5 \mu \mathrm{M}$ (i.e. $50 \%$ of initial DIN). The initial (and sub-mixed layer) semi-labile dissolved organics in the form of carbon (sDOM-C) and phosphorus (sDOM-P) were calculated from sDOM-N using the Redfield ratio.

\section{Results}

All simulations of the traditional paradigm demonstrated a significant period of oscillation before entering steady state (Fig. 3a; similar results were found using different $\mathrm{N}: \mathrm{P}$ nu-

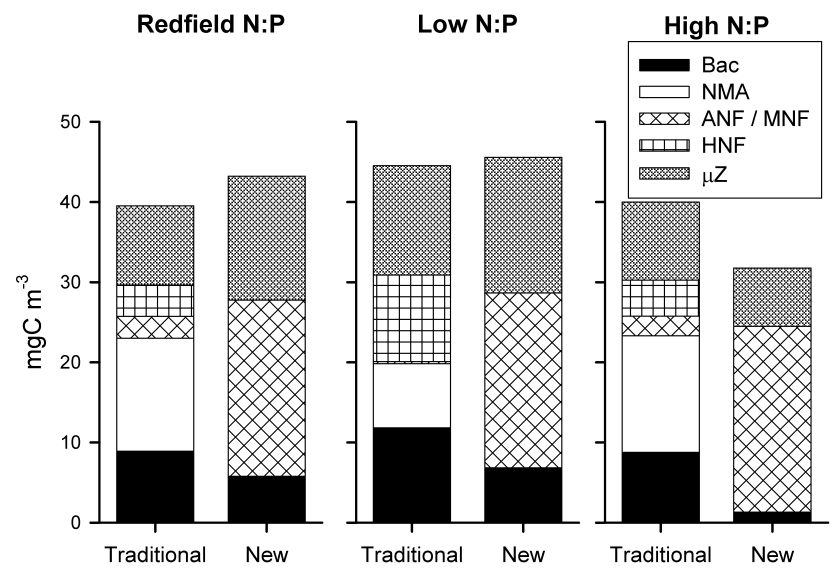

Fig. 4. Model output at steady state, showing the standing stock contributions to biomass of bacteria (Bac), non-motile microalgae (NMA), heterotrophic nanoflagellates (HNF), and the microzooplankton $(\mu \mathrm{Z})$. In the traditional paradigm, the flagellates capable of phototrophy (as ANFs) have no mixotrophic potential, while in the new paradigm they (as MNFs) exhibit mixotrophy (see also Figs. 2 and 3). The inorganic nutrient regimes (all with $1 \mu \mathrm{M}$ inorganic $\mathrm{N}$ ) are in Redfield $\mathrm{N}: \mathrm{P}$ (molar ratio 16 ), low $\mathrm{N}: \mathrm{P}$ (molar ratio 4), or high $\mathrm{N}$ : P (molar ratio 64).

trient ratios, not shown). On entering steady state, the ANFs were slowly eliminated due to their slightly slower emergent growth rate (lower by ca. $3 \%$ ) compared to that of the NMA.

In the simulations of the new paradigm, the predator-prey oscillations were muted in comparison with those seen in the traditional food web (Fig. 3b cf. 3a), and the system entered steady state much more rapidly. The NMA were eliminated as a consequence of their inability to compete with the MNFs. In addition, the HNFs were eliminated because they could not compete with the MNFs for bacterial prey. The advantage of the MNFs over both the NMA (for phototrophy) and the HNFs (for bacterivory) was attained through a synergistic co-operation between phototrophy and phagotrophy within the same organism. The results shown in Fig. $3 \mathrm{~b}$ are consistent with those of Hartmann et al. (2012), in that the dominance of bacterivory by HNFs expected under the traditional paradigm is replaced by a dominance of MNFs.

A comparison between steady-state standing stock Cbiomass levels for the different simulations is shown in Fig. 4. For Redfield $\mathrm{N}: \mathrm{P}$ and low $\mathrm{N}: \mathrm{P}$ nutrient configurations, the total plankton biomass was either slightly higher or essentially comparable in the traditional versus new paradigms. However, the new paradigm, with its lower bacterial biomass and higher biomass of larger celled $\mu \mathrm{Z}$, contained a higher biomass contribution by larger organisms (average ESD, $9 \mu \mathrm{m}$ for new paradigm simulations versus $7 \mu \mathrm{m}$ for traditional paradigm). In contrast, in the P-limited (high $\mathrm{N}: \mathrm{P})$ scenario, where again the MNFs dominated, the total plankton biomass and $\mu \mathrm{Z}$ biomass was lower for new versus traditional paradigm. Bacterial biomass was also much lower 

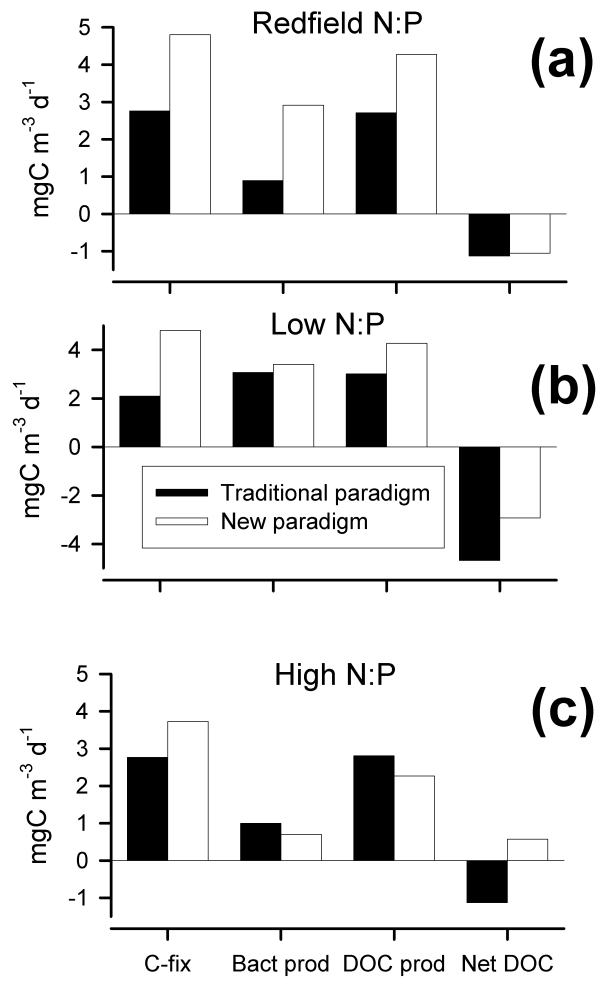

Fig. 5. Model output showing rates of primary production $(\mathrm{C}$ fix), bacterial production (Bact prod), production of DOC (from all sources, including voiding of material by grazers and primary production leakage, DOC prod), and net DOC (i.e. biological production of DOC - bacterial uptake of DOC; a negative value indicates that bacteria are reliant on DOC in part from outside of the mixed layer). In the traditional paradigm, the flagellates capable of phototrophy (ANFs) have no mixotrophic potential, while in the new paradigm, they (MNFs) exhibit mixotrophy (see also Figs. 2, 3 and 4). The inorganic nutrient regimes (all with an inorganic $\mathrm{N}$ input of $1 \mu \mathrm{M}$ ) are in Redfield $\mathrm{N}: \mathrm{P}$ (molar ratio 16; A), low N : P (molar ratio $4 ; \mathrm{B}$ ), or high $\mathrm{N}: \mathrm{P}$ (molar ratio $64 ; \mathrm{C}$ ).

in the new paradigm because of the higher abundance of their grazers (MNFs vs HNFs). The explanation for the decreased $\mu \mathrm{Z}$ in the new paradigm, despite the similar $\mathrm{C}$ biomass of their collective prey between paradigms, is the lower food quality; the HNFs, with their more closely matched lower $\mathrm{C}: \mathrm{N}$ and $\mathrm{C}: \mathrm{P}$, were scarce when MNFs were present. Other simulations with different nutrient concentrations and/or different light showed similar trends.

Comparisons of the primary, bacterial and DOC production in the different scenarios showed that, in every instance, primary production (C-fix, Fig. 5) was enhanced in the new paradigm, wherein $\mathrm{C}$ fixation is partly supported directly (through phagotrophy) by nutrients originally acquired by bacteria (Fig. 5). Production of DOC originating directly from primary production was similarly enhanced, but total DOC production (which includes DOC produced as SDOM-C through grazing activity) was lower in the high
$\mathrm{N}$ : P (P-limited) scenario of the new paradigm (Fig. 5) because of the lower $\mu \mathrm{Z}$ activity (Fig. 4). In all instances, planktonic net DOC production was always higher in the presence of mixotrophy (new paradigm); although under high $\mathrm{N}$ : $\mathrm{P}$, net DOC production was positive only with mixotrophy (Fig. 5c). In all the other scenarios, bacterial production was augmented through the use of dissolved organics mixed up into the upper layer. Although bacterial production in the new paradigm under high $\mathrm{N}: \mathrm{P}$ was lower than in the traditional paradigm, it was higher than one may expect from the standing stock (Fig. 4); this is because the lower bacterial biomass was more active (higher growth rate) in the new paradigm containing the mixotrophs.

\section{Discussion}

\subsection{Interpreting the simulations}

The results from the simulations recreate the pattern of a plankton community observed in oligotrophic waters (Zubkov and Tarran, 2008; Hartmann et al., 2012) comprised primarily of bacteria and mixotrophic flagellates. The HNFs and NMA, which separately were better competitors for bacteria and nutrients respectively, were ultimately excluded by the MNFs. The expected boom-and-bust predator-prey dynamics of the traditional paradigm did not occur in the new paradigm (Fig. 3a vs. 3b), indicating the stabilizing nature of mixotrophic nutrition. Algivory, rather than bacterivory, as the heterotrophic component in mixotrophs has been previously noted to enhance food web stability (Jost et al., 2004). In a maturing ecosystem such stability is important because instability would result in nutrients being lost from the system due to predator-prey mismatch (Flynn, 1989). The net result is the appearance of a stable plankton community, which displays different trophic dynamics than in the traditional paradigm.

A problem in modelling mixotrophy is that it is all too easy to configure an organism that is completely dominating - the "perfect beast" as termed by Flynn and Mitra (2009). In the past such an in silico outcome was considered to be at odds with reality. Now, however, it appears that mixotrophic protists are indeed nearly ubiquitous in mature ecosystems (Sanders, 1991a; Stoecker et al., 2009; Sanders and Gast, 2012; Flynn et al., 2013), though exceptions certainly occur (Arenovski et al., 1995; Sanders et al., 2000). The importance of mixotrophy has not been widely appreciated and embraced because traditional field and laboratory studies typically concentrate on strict phototrophs and strict phagotrophs; in addition, experimental protocols are typically suboptimal for elucidating the mixotrophic activities. Development of a sensitive, radiotracer-based experimental protocol (Zubkov and Tarran, 2008) enabled quantification of the major contribution of the phytoflagellates (formally considered to be strict phototrophs) to bacterivory in both mesotrophic and 
oligotrophic oceanic ecosystems (Zubkov and Tarran, 2008; Hartmann et al., 2012).

It appears that bacterivory, as well as predation upon larger organisms, is a potential nutritional acquisition route for many flagellates (Unrein et al., 2007; Burkholder et al., 2008; Jeong et al., 2010). Importantly though, this form of mixotrophy differs from the traditional expectation of two contributing nutritional pathways, both phototrophy and phagotrophy, contributing $\mathrm{C}, \mathrm{N}$, and P. Rather, mixotrophy in these protists appears synergistic and cooperative in its action: phagotrophy provides primarily $\mathrm{N}$ and $\mathrm{P}$ (and other non-carbon elements), whereas $\mathrm{C}$ acquisition happens mainly through photoautotrophy. This has several important consequences for studies of nutrient dynamics as listed below.

(i) Measurements using $\mathrm{C}$ as the tracer probably will not indicate the true importance of mixotrophy. In consequence, field measurements of mixotrophy need to deploy mixed tracers (i.e. not solely $\mathrm{C}$ tracers) and use a variety of approaches (Zubkov and Tarran, 2008; Calbet et al., 2012). Furthermore, significant changes in photosynthesis may or may not be expected (depending on the fate of the prey $\mathrm{C}$ ).

(ii) Phago-mixotrophy by protists with a constitutive (intrinsic) ability to photosynthesize (as simulated here; see also Flynn and Hansen, 2013) probably provides nutrients that are ultimately handled by the cells' photo-dominated physiology in a similar fashion to inorganic nutrients. In consequence, depending on the $\mathrm{C}: \mathrm{N}: \mathrm{P}$ of the prey there is scope for enhanced DOM$\mathrm{C}$ release as a function of phagotrophy, both through non-assimilation of some portion of the prey $\mathrm{C}$ and through DOM production as some portion of the continuing C-fixation process (Flynn et al., 2008).

(iii) Models of mixotrophy and of its role in the biological pump need to be multi-element-based $(\mathrm{C}, \mathrm{N}$, $\mathrm{P}$, etc.); otherwise they cannot capture the synergistic/cooperative nature of the interactions. In addition, variability in stoichiometry is an important feature in simulating the dynamics of predation (Grover, 2003; Mitra and Flynn, 2005; Glibert et al., 2011). In the simulations presented here, the MNFs did not win by eating their competitors (eating the HNFs or nonphagotrophic microalgae; cf. Thingstad et al., 1996). Instead, they succeeded through a combination of cooperative nutrition and, especially in the low-P simulations, through having a disadvantageous stoichiometric content (i.e. poor-quality food for $\mu \mathrm{Z}$ ). Even though the nutritional routes (phototrophy vs. phagotrophy) are not fully substitutable, an additional factor in favour of mixotrophy is that (similar to that mentioned in Tittel et al., 2003) the combination of nutritional routes enables the mixotrophs to consume resources down to levels below the critical thresholds required to support effective growth by either of the non-mixotrophic NMA and HNFs.

Oligotrophic systems are low in phosphorus (high $\mathrm{N}: \mathrm{P}$ ), although as nutrient concentrations become vanishingly low the critical $\mathrm{N}$ : $\mathrm{P}$ ratio for equal $\mathrm{N}$ and $\mathrm{P}$ sufficiency decreases (Flynn, 2010). It is interesting to note that the modelled high $\mathrm{N}$ : P scenario behaved differently than the others and was the only scenario that resulted in net production of DOM (Fig. 5). Taking everything into account, the events seen for the high $\mathrm{N}: \mathrm{P}$ scenario arise because (1) the mixotrophs release DOC that supports bacterial acquisition of the nutrients, (2) the mixotrophs then acquire those nutrients directly through consumption of the bacteria, (3) this acquisition is insufficient to match the total nutritional demand by the mixotrophs (due to $\mathrm{P}$ deficiency in the environment), and therefore (4) the $\mathrm{C}: \mathrm{N}: \mathrm{P}$ of the mixotrophs is/remains disadvantageous (of poor quality) to the $\mu \mathrm{Z}$ predators. In essence, the dominance of the mixotrophs in the P-limited high $\mathrm{N}: \mathrm{P}$ system developed through a process not dissimilar to that proposed by Mitra and Flynn (2006b) for the formation of an ecosystemdisruptive harmful algal bloom (EDAB; Sunda et al., 2006). This development of a bloom could be considered to represent a product of a dysfunctional microbial loop (Thingstad et al., 1997), in that the transmission of $C$ and energy up through $\mu \mathrm{Z}$ to higher trophic levels is restricted. Either way, a system is created that generates DOM via the "microbial carbon pump" that some (Azam and Worden, 2004; Hansell et al., 2009; Jiao et al., 2010) have suggested to represent an additional contributor to the biological pump.

\subsection{The new paradigm for marine plankton food web and implications for the biological pump}

An appreciation of the existence of protist mixotrophs is not new. What is new is the realisation that these organisms are major players in the planktonic food web, contributing substantially to the flow of carbon and other nutrients in aquatic ecosystems. It is thus appropriate to ask whether this realisation warrants a revision of our understanding and simulation of food web dynamics and allied biogeochemistry coupled to the biological pump.

Figure 6 presents, in simplified form, the bacteria-centric parts of the food web (Fig. 2), as we have explored through simulations. In the traditional paradigm (Fig. 6a), DOM release from phototrophy supports growth of bacteria, which then enables them, on an individual cell basis (due to their smaller size), to outcompete phototrophs (microalgae, Fig. 6) for nutrients. Grazing on bacteria by microzooplankton (specifically HNFs, and then by larger $\mu \mathrm{Z}$ ) provides the main route for nutrient regeneration in the traditional paradigm (yellow arrow in Fig. 6a); this is due to stoichiometric constraints linked to respiration and an inability of assimilation efficiencies to approach $100 \%$ (Mitra and Flynn, 2005). In the new paradigm (Fig. 6b), DOM release from phototrophy again supports growth of bacteria, 
(a) TRADITIONAL PARADIGM

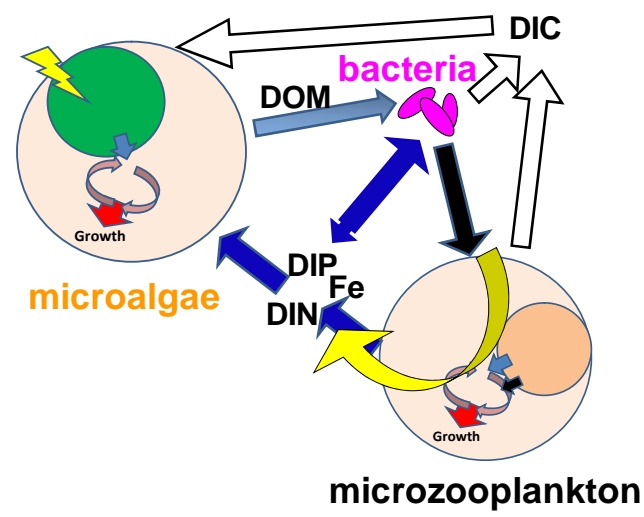

(b) NEW PARADIGM

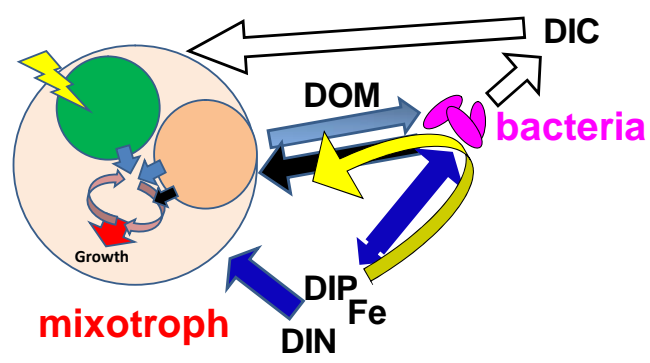

Fig. 6. Schematic showing the detailed involvement of bacteria and DOM for the supply of nutrients to support primary production (yellow arrows) in the traditional paradigm (A) versus the new paradigm (B). See Sect. 4.2. Black arrows indicate predatory links.

enabling them to acquire inorganic nutrients unavailable to the phototrophic protists. However, grazing on bacteria by these protists now acts through mixotrophy as a direct conduit for the support of primary production (yellow arrow in Fig. 6b). This could be considered akin to a symbiotic or mutualistic relationship between phototrophy and heterotrophy (as discussed in the context of primary production by Flynn, 1988), or a relationship wherein the bacteria are being farmed by the mixotrophs. The consequence is that primary production can now be supported by nutrients that would otherwise be unavailable (present at very low concentrations, and/or in combined forms of DOM that are not chemically suitable for transport into the protist cell).

Both the bacteria (with extracellular digestion) and the mixotrophs (through voiding of unrequired complex compounds of bacterial origin) will generate DOM that will over time become increasingly refractory and hence accumulate. Indeed, in the simulations, especially in the high $\mathrm{N}: \mathrm{P}(\mathrm{P}-$ limiting) scenario, the net DOM-C increased (Fig. 5c). The extent to which DOM-C contributes to a biological pump (Hansell et al., 2009) depends on the removal of this material into deeper water, away from abiotic processes (no- tably sunlight and oxygen) that would promote its degradation. Presumably any contribution of DOM-C to the biological pump is (similar to the abiotic removal of $\mathrm{CO}_{2}$ into cold waters) only of transient importance in mitigating the increasing atmospheric $\mathrm{CO}_{2}$ (otherwise, concentrations of DOM must be increasing over the millennia). Nonetheless, it could be important and merits consideration in long-term forecast models.

\subsection{Climate change, eutrophication and mixotrophy}

Climate and anthropogenic changes to the marine ecosystem include an increase in water column stability (Doney et al., 2009, but cf. Lozier et al., 2011), and changes if not increases to coastal eutrophication (Burkholder et al., 2008; Burkholder and Glibert, 2013). Both of these events are likely to favour the growth of mixotrophic plankton, including potentially harmful algal bloom (HAB) species (noting that HABs are dominated by mixotrophic forms; Burkholder et al., 2008). Along with this we may expect to see changes in plankton trophic dynamics, and in the functioning of the biological pump.

Temporal and spatial events that see mixotrophs as important members of the plankton include survival and growth of larval fish in temperate waters (de Figueiredo et al., 2007; Montagnes et al., 2010), and production in the oligotrophic systems that cover most of the oceans (Pitta and Giannakourou, 2000; Unrein et al., 2007; Zubkov and Tarran, 2008; Stukel et al., 2011; Hartmann et al., 2012). The interplay between nutrient stoichiometry, ecosystem maturity and success of mixotrophy also helps to explain why eutrophication is often associated with mixotrophic HABs and EDABs (Burkholder et al., 2008; Glibert and Burkholder, 2011; Burkholder and Glibert, 2013). It also explains why many offshore mixotroph-dominated bloom events are difficult to relate to land-based nutrient sources when, in fact, they are related (Anderson et al., 2011; Harrison et al., 2011). Offshore blooms of mixotrophic species may, in fact, be the successional endpoint of near-shore nutrient loading and nutrient stoichiometric shifts. For example, some offshore blooms of the green mixotrophic Noctiluca scintillans are now recognized to be the displaced result of near-shore eutrophication (Harrison et al., 2011). The future would likely see an expansion of such events unless steps are taken to control eutrophication.

Acknowledging the importance of mixotrophy is not simply a case of recognizing mixotrophs as significant; it is of recognising the significance of mixotrophy in organisms that we already know to be important. While many aspects of mixotroph physiology remain enigmatic, they offer fertile ground for investigation by aquatic ecologists and thus improve understanding of aquatic food webs and elemental cycles in theoretical and computational ecological modelling. The work reported in this paper, together with that of Mitra and Flynn (2010), has demonstrated the 
importance of providing an explicit multi-nutrient description of mixotrophy in models if we are to simulate these events adequately. Only through such efforts will we better understand the future contribution of mixotrophy to the biological pump as well as to food security issues (as feed for fisheries, Montagnes et al., 2010, vs. HABs, Burkholder et al., 2008) and interactions with climate change in shaping marine plankton assemblages.

Acknowledgements. Construction, validation and application of models were funded through grants awarded by the Natural Environment Research Council (UK) to A. Mitra and K. J. Flynn. All authors acknowledge the Leverhulme Trust for their funding of an International Network Grant. A. Calbet was partially supported by the Ministry of Science and Innovation of Spain through project PROTOS (CTM2009-08783). A. Mitra was supported in part by project EURO-BASIN (Ref. 264933, 7FP, European Union). D. K. Stoecker was partially supported by NSF award 1031344. J. Hawkey assisted with graphic preparation. A. Mitra thanks Rohan Mitra-Flynn for his continuing support. This is contribution number 4789 from UMCES. The University of Dundee is a registered charity, no. SC010596.

Edited by: G. Herndl

\section{References}

Anderson, C. R., Kudela, R. M., Benitez-Nelson, C., Sekula-Wood, E., Burrell, C. T., Chao, Y., Langlois, G., Goodman, J., and Siegel, D. A.: Detecting toxic diatom blooms from ocean color and a regional ocean model, Geophys. Res. Lett. 38, LO4603, doi:10.1029/2010GL045858, 2011.

Andersson, A., Larsson, U., and Hagström, A.: Size-selective grazing by a microflagellate on pelagic bacteria, Mar. Ecol. Prog. Ser., 33, 51-57, 1986.

Arenovski, A. L., Lim, E. L., and Caron, D.A.: Mixotrophic nanoplankton in oligotrophic surface waters of the Sargosso Sea may employ phagotrophy to obtain major nutrients, J. Plankton Res., 17, 801-820, 1995.

Azam, F. and Worden, A. Z.: Microbes, molecules, and marine ecosystems, Science, 303, 1622-1624, 2004.

Azam, F., Fenchel, T., Field, J. G., Gray, J. S., Meyer-Reil, L. A., and Thingstad, F.: The ecological role of water-column microbes in the sea, Mar. Ecol. Prog. Ser., 10, 257-263, 1983.

Burkholder, J. M. and Glibert, P. M.: Eutrophication and oligotrophication, in: Encyclopedia of Biodiversity, edited by: Levin, S., 2nd Edn., Vol. 3, Academic Press, Waltham (Massachusetts), 347-371, 2013.

Burkholder, J. M., Glibert, P. M., and Skelton, H. M.: Mixotrophy, a major mode of nutrition for harmful algal species in eutrophic waters, Harmful Algae, 8, 77-93, 2008.
Calbet, A., Martínez, R. A., Isari, S., Zervoudaki, S., Nejstgaard, J. C., Pitta, P., Sazhin, A. F., Sousoni, D., Gomes, A., Berger, S. A., Stagaraki, T. M., and Ptacnik, R.: Effects of light availability on mixotrophy and microzooplankton grazing in an oligotrophic plankton food web: evidences from a mesocosm study in Eastern Mediterranean waters, J. Exp. Mar. Biol. Ecol., 424-425, 66-77, 2012.

Croft, M. T., Warren, M. J., and Smith, A. G., Algae need their vitamins, Eukaryotic Cell, 5, 1175-1183, 2006.

Cushing, D. H.: Marine Ecology and Fisheries, Cambridge University Press, Cambridge, 1975.

Cushing, D. H.: Population production and regulation in the sea, A fisheries perspective, Cambridge University Press, Cambridge, UK, 1995.

de Castro, F., Gaedke, U., and Boenigk, J.: Reverse evolution: driving forces behind the loss of acquired photosynthetic traits, PloS ONE 4:e8465, doi:10.1371/journal.pone.0008465, 2009.

de Figueiredo, G. M., Nash, R. D. M., and Montagnes, D. J. S.: Do protozoa contribute significantly to the diet of larval fish in the Irish Sea?, J. Mar. Biol. Ass. UK, 87, 843-850, 2007.

Doney, S. C., Fabrey, V. J., Feely, R. A., and Kleypas, J. A.: Ocean acidification: the other $\mathrm{CO}_{2}$ problem, Annu. Rev. Mar. Sci., 1, 189-192, 2009.

Fasham, M. J. R., Ducklow, H. W., and McKelvie, S. M.: A nitrogen-based model of plankton dynamics in the oceanic mixed layer, J. Mar. Res., 48, 591-639, 1990.

Field, C., Behrenfeld, M. J., Randerson, J. T., and Falkowski, P.: Primary production of the biosphere: integrating terrestrial and oceanic components, Science, 281, 237-240, 1998.

Flynn, K. J.: The concept of "primary production" in aquatic ecology, Limnol. Oceanogr., 33, 1215-1216, 1988.

Flynn, K. J.: Interaction between nutrient and predator limitation of production in the marine euphotic zone, Chem. Ecol., 4, 21-36, 1989.

Flynn, K. J.: A mechanistic model for describing dynamic multinutrient, light, temperature interactions in phytoplankton, J. Plankton Res., 23, 977-997, 2001.

Flynn, K. J.: Incorporating plankton respiration in models of aquatic ecosystem function, in: Respiration in aquatic ecosystems, edited by: del Giorgio, P. A. and Williams, LeB, P. J., Oxford University Press, 248-266, 2005.

Flynn, K. J.: Do external resource ratios matter? Implications for modelling eutrophication events and controlling harmful algal blooms, J. Mar. Sys., 83, 170-180, 2010.

Flynn, K. J. and Hansen, P. J.: Cutting the canopy to defeat the "selfish gene"; conflicting selection pressures for the integration of phototrophy in mixotrophic protists, Protist, 164, 811-823, 2013.

Flynn, K. J. and Mitra, A.: Building the "perfect beast": modelling mixotrophic plankton, J. Plankton Res., 31, 965-992, 2009.

Flynn, K. J., Clark, D. R., and Xue, Y.: Modelling the release of dissolved organic matter by phytoplankton, J. Phycol., 44, 11711187, 2008.

Flynn, K. J., Stoecker, D. K., Mitra, A., Raven, J. A., Glibert, P. M., Hansen, P. J., Granéli, E., and Burkholder, J. M.: A case of mistaken identification: the importance of mixotrophy and the clarification of plankton functional-classification, J. Plankton Res., 35, 3-11, 2013.

Gifford, D. J.: The protozoan-metazoan trophic link in pelagic ecosystems, J. Protozool., 38, 81-86, 1991. 
Glibert, P. M. and Burkholder, J. M.: Eutrophication and HABs: Strategies for nutrient uptake and growth outside the Redfield comfort zone, Chin. J. Oceanol. Limnol., 29, 724-738, 2011.

Glibert, P. M. and Legrand, C.: The diverse nutrient strategies of harmful algae: focus on osmotrophy, 163-175, in: The Ecology of Harmful Algae, edited by: Granéli, E. and Turner, J., SpringerVerlag, New York, 2005.

Glibert, P. M., Fullerton, D., Burkholder, J. M., Cornwell, J. C., and Kana, T. M.: Ecological stoichiometry, biogeochemical cycling, invasive species and aquatic food webs: San Francisco Estuary and comparative systems, Rev. Fish. Sci., 19, 358-417, 2011.

Grover, J. P.: The impact of variable stoichiometry on predator-prey interactions: a multinutrient approach, Am. Nat., 162, 29-43, 2003.

Hansell, D. A., Carlson, C. A., Repeta, D. J., and Schlitzer, R.: Dissolved organic matter in the ocean - a controversy stimulates new insights, Oceanogr., 22, 202-211, 2009.

Hansen, P. J.: The role of photosynthesis and food uptake for the growth of marine mixotrophic dinoflagellates, J. Eukaryot. Microbiol., 58, 203-214, 2011.

Harrison, P. J., Furuya, K., Glibert, P. M., Xu, J., Liu, H. B., Yin, K., Lee, J. H. W., Anderson, D. M., Gowen, R., Al-Azri, A. R., and Ho, A. Y. T.: Geographical distribution of red and green Noctiluca scintillans, Chin. J. Oceanol. Limnol., 29, 807-831, 2011.

Hartmann, M., Grob, C., Tarran, G. A., Martin, A. P., Burkill, P. H., Scanlan, D. J., and Zubkov, M. V.: Mixotrophic basis of Atlantic oligotrophic ecosystems, Proc. Nat. Acad. Sci., 109, 5756-5760, 2012.

Irigoien, X., Flynn, K. J., and Harris, R. P.: Phytoplankton blooms: A "loophole" in microzooplankton grazing impact? J. Plankton. Res., 27, 313-321, 2005.

Jeong, H. J, Yoo, Y. D., Kim, J. S., Seong, K. A., Kang, N. S., and Kim, T. H.: Growth, feeding and ecological roles of the mixotrophic and heterotrophic dinoflagellates in marine planktonic food webs, Ocean Sci. J., 45, 65-91, 2010.

Jiao, N., Herndl, G. J., Hansell, D. A., Benner, R., Kattner, G., Wilhelm, S. W., Kirchman, D. L., Weinbauer, S. W., Luo, T., Chen, F., and Azam, F. Microbial production of recalcitrant dissolved organic matter: long-term carbon storage in the global ocean, Nature Rev. Microbiol., 8, 593-599, 2010.

Johnson, M. D.: Acquired phototrophy in ciliates: a review of cellular interactions and structural adaptations, J. Eukaryot. Microbiol., 58, 41-54, 2011.

Jost, C., Lawrence, C. A., Campolongo, F., van de Bund, W., Hill, S., and DeAngelis, D. L.: The effects of mixotrophy on the stability and dynamics of a simple planktonic food web model, Theor. Popul. Biol., 66, 37-51, 2004.

Lindehoff, E., Granéli, E., and Glibert, P. M.: Influence of prey and nutritional status on the rate of nitrogen uptake by Prymnesium parvum (Haptophyte), J. Am. Water Resour. Ass., 46, 121-132, 2010.

Lozier, M. S., Dave, A. C., Palter, J. B., Gerber, L. M., and Barber, R. T.: On the relationship between stratification and primary productivity in the North Atlantic, Geophys. Res. Lett., 38, L18609, doi:10.1029/2011GL049414, 2011.

Mitra, A.: A multi-nutrient model for the description of stoichiometric modulation of predation (SMP) in micro- and mesozooplankton, J. Plankton Res., 28,597-611, 2006.
Mitra, A.: Are closure terms appropriate or necessary descriptors of zooplankton loss in nitrogen - phytoplankton - zooplankton models? Ecol. Model., 220, 611-620, 2009.

Mitra, A. and Flynn, K. J.: Predator-prey interactions: is "ecological stoichiometry" sufficient when good food goes bad?, J. Plankton Res., 27, 393-399, 2005.

Mitra, A. and Flynn, K. J.: Accounting for variation in prey selectivity by zooplankton, Ecol. Model., 199, 82-92, 2006a.

Mitra, A. and Flynn, K. J.: Promotion of harmful algal blooms by zooplankton predatory activity, Biol. Lett., 2, 194-197, $2006 \mathrm{~b}$.

Mitra, A. and Flynn, K. J.: Modelling mixotrophy in harmful algal blooms: More or less the sum of the parts?, J. Mar. Sys., 83, 158 169,2010

Mitra, A., Flynn, K. J., and Fasham, M. J. R.: Accounting correctly for grazing dynamics in Nutrient-Phytoplankton-Zooplankton models, Limnol. Oceanogr., 52, 649-661, 2006.

Mitra, A., Castellani, C., Gentleman, W. C., Jónasdóttir, S. H., Flynn, K. J., Bode, A., Halsband, C., Kuhn, P., Licandro, P., Agersted, M. D., Calbet, A., Lindeque, P., Koppelmann, R., Møller, E. F., Gislason, A., Nielsen, T. G., and St. John, M. Bridging the gap between marine biogeochemical and fisheries sciences; configuring the zooplankton link, Prog. Oceanogr., in press, 2014.

Montagnes, D. J. S., Dower, J. F., and Figueiredo, G. M.: The protozooplankton-ichthyoplankton trophic link: an overlooked aspect of aquatic food webs, J. Eukaryot. Microbiol., 57, 223228, 2010.

Odum, E. P.: The strategy of ecosystem development, Science, 164, 262-270, 1969.

Parry, G. D.: The meaning of r- and K-selection, Oecologia, 48, 260-264, 1981.

Pérez, M. T., Dolan, J. R., and Fukai, E.: Planktonic oligotrich ciliates in the NW Mediterranean: growth rates and consumption by copepods, Mar. Ecol. Prog. Ser., 155, 89-101, 1997.

Pitta, P. and Giannakourou, A.: Planktonic ciliates in the oligotrophic Eastern Mediterranean: vertical, spatial distribution and mixotrophy, Mar. Ecol. Prog. Ser., 194, 269-282, 2000.

Polovina, J. J., Howell, E. A., and Abecassis, M.: Ocean's least productive waters are expanding, Geophys. Res. Lett., 35, L03618, doi:10.1029/2007GL031745, 2008.

Raven, J. A., Beardall, J., Flynn, K. J., and Maberly, S. C.: Phagotrophy in the origins of photosynthesis in eukaryotes and as a complementary mode of nutrition in phototrophs: relation to Darwin's Insectivorous Plants, J. Exp. Bot., 60, 3975-3987, 2009.

Redfield, A. C.: The biological control of chemical factors in the environment, Am. Sci., 46, 205-221, 1958.

Rokitta, S. D., de Nooijer, L. J., Trimborn, S., de Vargas, C., Rost, B, and John, U.: Transcriptional analyses reveal differential gene expression patterns between the life cycle stages of Emiliania huxleyi (Haptophyta) and reflects specialization to different ecological niches, J. Phycol., 47, 829-838, 2011.

Rose, K. A., Allen, J. I., Artioli, Y., Barange, M., Blackford, J., Carlotti, F., Cropp, R., Daewel, U., Edwards, K., Flynn, K. J., Hill, S. L., HilleRisLambers, R., Huse, G., Mackinson, S., Megrey, B., Moll, A., Rivkin, R., Salihoglu, B., Schrum, C., Shannon, L., Shin, Y-J., Smith, S. L., Smith, C., Solidoro, C., St. John, M., and Zhou, M.: End-To-End models for the analysis of marine ecosystems: challenges, issues, and next steps, Mar. Coastal Fisheries: 
Dynamics, Management, and Ecosystem Science, 2, 115-130, 2010.

Sanders, R. W.: Mixotrophic protists in marine and freshwater ecosystems, J. Protozool., 38, 76-81, 1991a.

Sanders, R. W.: Trophic strategies among heterotrophic flagellates, in: The Biology of Heterotrophic Flagellates, edited by: Patterson, D. J. and Larsen, J., Systematics Association, Oxford University Press, 1991 b.

Sanders, R. W. and Gast, R. J.: Bacterivory by phototrophic picoplankton and nanoplankton in Arctic waters, FEMS Microbiol. Ecol., 82, 242-253, 2012.

Sanders, R. W., Berninger, U.-G., Lim, E. L., Kemp, P. F., and Caron, D. A.: Heterotrophic and mixotrophic nanoplankton predation on picoplankton in the Sargasso Sea and on Georges Bank, Mar. Ecol. Prog. Ser., 192, 103-118, 2000.

Sherr, E. B. and Sherr, B. F.: Significance of predation by protists in aquatic microbial food webs, Antonie van Leeuwenhoek, 81, 293-308, 2002.

Steele, J. H., Thorpe, S. A., and Turekian, K. K.: Marine Ecological Processes: A derivative of the Encyclopedia of Ocean Sciences, Elsevier, Academic Press, London, 2010.

Stoecker, D. K., Johnson, M. D., de Vargas, C., and Not, F.: Acquired phototrophy in aquatic protists, Aquat. Microb. Ecol., 57, 279-310, 2009.

Stukel, M. R., Landry, M. R., and Selph, K. E.: Nanoplankton mixotrophy in the eastern equatorial Pacific, Deep-Sea Res. II, 58, 378-386, 2011.
Sunda, W. G., Granéli, E., and Gobler, C.: Positive feedback and the development and persistence of ecosystem disruptive algal blooms, J. Phycol., 42, 963-974, 2006.

Thingstad, F. T., Havskum, H., Garde, K., and Riemann, B.: On the strategy of "eating your competitor": a mathematical analysis of algal mixotrophy, Ecology, 77, 2108-2118, 1996.

Thingstad, F. T., Hagström, A., and Rassoulzadegan, F.: Accumulation of degradable DOC in surface waters: Is it caused by a malfunctioning microbial loop?, Limnol. Oceanogr., 42, 398-404, 1997.

Tittel, J., Bissinger, V., Zippel, B., Gaedke, U., Bell, E., Lorke, A., and Kamjunke, N.: Mixotrophs combine resource use to outcompete specialists: implications for aquatic food webs, Proc. Natl. Acad. Sci., 100, 12776-12781, 2003.

Totterdell, I. J., Armstrong, R. A., Drange, H., Parslow, J. S., Powell, T. M., and Taylor, A.: Trophic resolution, in: Towards a Model of Ocean Biogeochemical Processes, edited by: Evans, G. T. and Fasham, M. J. R., NATO ASI, I:10 Springer-Verlag, Berlin, 1993.

Unrein, F., Massana, R., Alonso-Sáez, L., and Gasol, J. M.: Significant year-round effect of small mixotrophic flagellates on bacterioplankton in an oligotrophic coastal system, Limnol. Oceanogr., 52, 456-469, 2007.

Zubkov, M. V. and Tarran, G. A.: High bacterivory by the smallest phytoplankton in the North Atlantic Ocean, Nature, 455, 224226, 2008. 